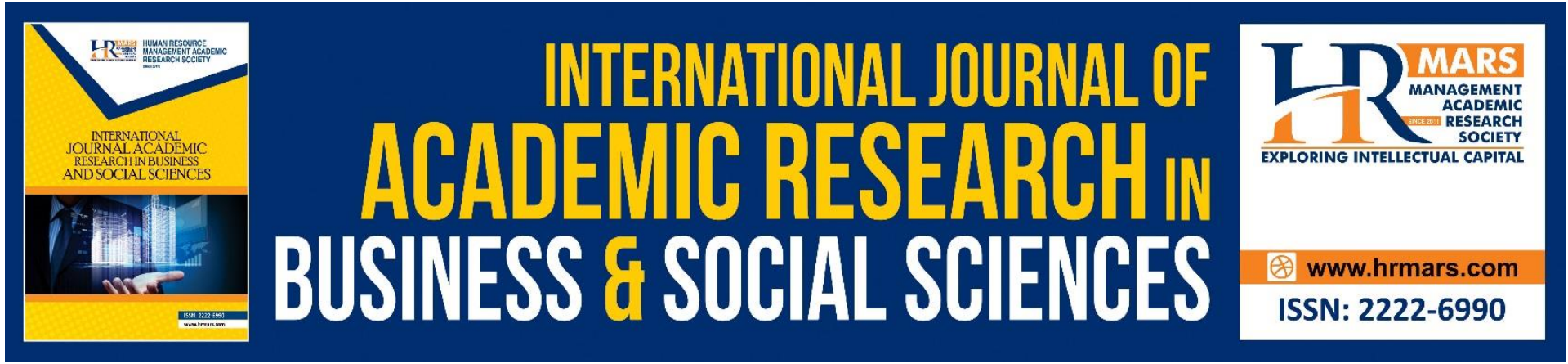

\title{
Roles of Technology Usage in Cash Waqf Contribution: Factors to Enhance Collection of Cash Waqf in Malaysia
}

\section{Wan Musyirah Wan Ismail, Mohamed Saladin Bin Abdul Rasool}

To Link this Article: http://dx.doi.org/10.6007/IJARBSS/v11-i8/10803

DOI:10.6007/IJARBSS/v11-i8/10803

Received: 04 June 2021, Revised: 30 June 2021, Accepted: 18 July 2021

Published Online: 15 August 2021

In-Text Citation: (Ismail \& Rasool, 2021)

To Cite this Article: Ismail, W. M. W., \& Rasool, M. S. B. A. (2021). Roles of Technology Usage in Cash Waqf Contribution: Factors to Enhance Collection of Cash Waqf in Malaysia. International Journal of Academic Research in Business and Social Sciences, 11(8), 1136-1146.

\section{Copyright: @ 2021 The Author(s)}

Published by Human Resource Management Academic Research Society (www.hrmars.com)

This article is published under the Creative Commons Attribution (CC BY 4.0) license. Anyone may reproduce, distribute, translate and create derivative works of this article (for both commercial and non-commercial purposes), subject to full attribution to the original publication and authors. The full terms of this license may be seen at: http://creativecommons.org/licences/by/4.0/legalcode

Vol. 11, No. 8, 2021, Pg. 1136 - 1146

Full Terms \& Conditions of access and use can be found at http://hrmars.com/index.php/pages/detail/publication-ethics 


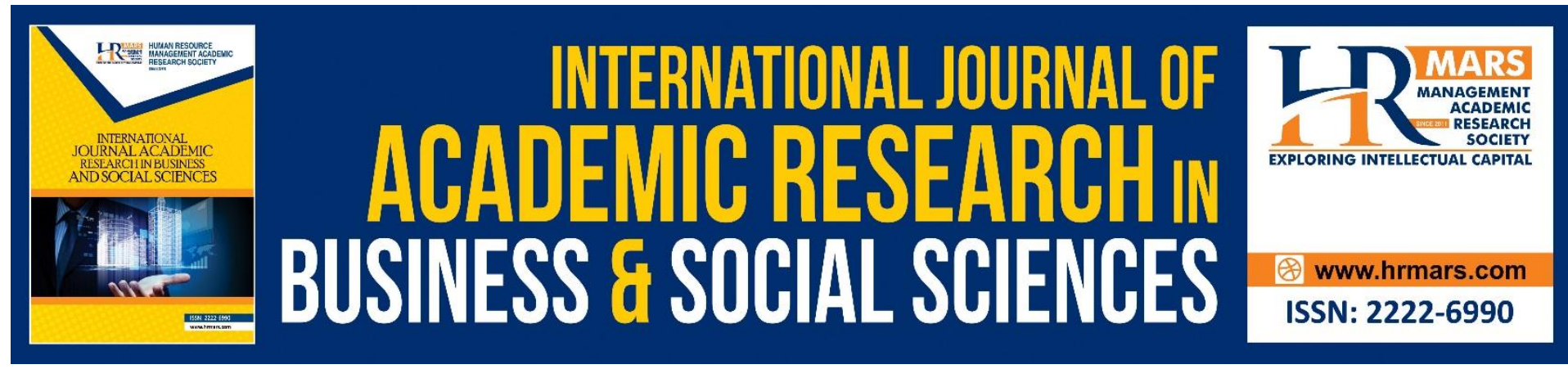

\title{
Roles of Technology Usage in Cash Waqf Contribution: Factors to Enhance Collection of Cash Waqf in Malaysia
}

\author{
Wan Musyirah Wan Ismail, Mohamed Saladin Bin Abdul Rasool \\ ${ }^{1}$ Finance and Economy Department, Faculty of Business and Management, Universiti \\ Teknologi Mara, Melaka, Malaysia, ${ }^{2}$ Finance and Economy Department, Faculty of Business \\ and Management, Universiti Teknologi Mara, Melaka, Malaysia \\ Email: musyirah792@uitm.edu.my,saladin@uitm.edu.my
}

\begin{abstract}
The introduction of cash waqf in Malaysia casts a new light on the creation of policies for enhancing the quality of life of those who are impoverished. Malaysia's fast expansion of cash waqf has reached new heights in recent years. One of the contributing elements to this issue is a growing awareness among the general population. The religious state department and waqf centres in Malaysia are also active in developing more contemporary waqf instruments that are beneficial to the general public. This increases the prospects of cash waqf to play a more prominent role in poverty alleviating initiatives in Malaysia. It is because, cash waqf is one of the alternative instruments that can overall improve the social welfare and reduce the poverty rate and at the same time, lessen the burden of the government. However, the collection of cash waqf fund in Malaysia is something that could be improved due to the total amount collected did not reflect the total amount of Muslim population in Malaysia. Hence, there is a need to find the best method to improve the collection of cash waqf. In line with technology advancement, it is expected that technology adoption in the method of collection cash waqf could be a steppingstone to increase the amount of fund. With this reason, technology usage is aims to be the factor that would enhance the contribution of cash waqf. This study used 284 respondents who were employed Muslims to investigate the effect of technology usage in influence intention of individual to contribute cash waqf. This study used Partial Least Squares Structural Equation Modeling (PLS-SEM) to analyse data through correlation analysis. Referring to the correlation analysis, the finding discovered that there is a positive and strong relationship between technology usage and intention of cash waqf contribution. This could be concluded the roles of technology usage in influence people's intention for cash waqf contribution.
\end{abstract}

Keywords: Cash Waqf, Technology Advancement, Technology Usage.

\section{Introduction}

Cash waqf can be defined as a distribution of wealth in cash to build institutions such as schools and mosques that can benefit the society or community. Cash waqf had been proven successful during the Ottoman Caliphate which was used for education, food, 
maintenance of waqf buildings and mosques. Due to the various benefits of cash waqf, the National Fatwa Council has authorized its implementation in Malaysia. For example, Selangor offers cash waqf as low as RM10 per unit to encourage the public to contribute cash waqf (Osman et al., 2014).

An application of cash waqf existed to create a method for making waqf more flexible. Cash waqf is as an alternative to those who are unable to contribute property for the waqf purpose. Khademolhoseini, (2008) defined cash waqf as giving some money from one's possession to perform waqf based on that amount. Then the money will be given to eligible people to receive the benefits from the return of waqf. The contribution of cash waqf must be used for the community's development and the benefit is to be used by the public. Besides that, the money collected from cash waqf may be invested in the real sector or in any Shariah investment for the purpose to cycle the money for the sake of waqf property development.

This research aims to investigate the roles of tehnology usage in order to enhance the contribution of cash waqf among Muslims in Malaysia.

\section{Problem Statement}

The collection of cash waqf fund in Malaysia is very low because the total amount collected did not reflect the total amount of Muslim population in Malaysia (Mat Doa, 2020). Based on report by Yayasan Wakaf Malaysia (YWM) calculation, (Mat Doa, 2020), the average cash waqf per employed Muslim for 2019 was only RM0.28 per employed person. Fuadah Johari, the Deputy Director Islamic Finance Wealth Management Institution (Johari, 2020), highlighted RM0.28 per employed Muslim is just a small fraction of cash waqf contribution. Though cash waqf has been gazetted 13 years ago in the $77^{\text {th }}$ Majlis Fatwa Kebangsaan Muzakarah in 2007, the collection is still low due to the lack of awareness among the Muslims in Malaysia (Jalil et al., 2017; Allah Pitchay et al., 2018; Ab Fatah et al., 2017; Adeyemi et al., 2016). This could be an obstacle to the development of the country because cash waqf plays a big role in the country's economy and society and plays a vital role in the advancement of socio economic wellbeing of the Muslim community (Mahbubi, 2017).

In order to improve the collection of Cash Waqf, technology seems to be one of the solutions. Technology is a key channel in the financial sector, and it will be an opportunity for them to increase their efficiency in achieving their objectives. Technology can also provide a better experience and convenience for users (Devadevan, 2013). Mohd Isa (2014); Ahmad et. al (2014); Nasiri (2019) study on the acceptance of online Cash Waqf which adoption of technology in the Cash Waqf collection system.

However, Amin et al (2014) stated that acceptance of online waqf contribution among the public is still at infancy level. This was supported by Ahmad et al. (2014) and Ahmad \& Muhamed (2011) who found that age influences the acceptance of technology used for waqf collection. Shukor et al (2017) cited convenience in contributing cash waqf is vital to encourage contribution of cash waqf. It can be achieved by providing greater access to online facilities which can reach the young, who are IT literate generation to promote online waqf thus, making them the target group to use technology for cash waqf system. Age might be an issue on the acceptance of technology (Peek et al., 2014); thus, new research are recommended to be conducted.

With the suggestion by with Hasanah \& Pranata, (2019); Fauzi, Yahya, Haron, et al. (2019); Adeyemi et al (2016) proposed that applying technology advancement in cash waqf makes the waqf collection more efficient and effective. It is strongly supported by Wadi \& Nurzaman, (2020), who are mentioned that, today there are many digital industry has also 
entered social services. Various social service platforms are present to facilitate donation. Nevertheless, there are still very few platforms engaged in waqf. Existing waqf platform is considered to be not succeeding in cultivating waqf. Furthermore, Ani, (2019) reported in Indonesia, only 225 billion rupiah of waqf funds have been collected from a potential of 77 trillion rupiah per year, even though Indonesia has been stated as the most philanthropist people in the world. This huge gap is an obvious sign that Indonesia needs to have a better understanding about waqf technology adoption. It is because, most researchers in waqf issue so far have been only focusing on traditional or conventional waqf participation. Whereas knowledge related to these are important to know considering the current trend transformation towards digital conducted by various institutions. This gap could be fulfilled with the study to investigate the relevance of technology acceptance and usage in cash waqf sector, especially in the method of collection of cash waqf. In line with this, the study aims to investigate the roles of technology usage in enhancing cash waqf contribution.

\section{Literature Review}

The implementation of cash waqf in Malaysia is done after the decision made in 2007 in the meeting by the Malaysian Islamic National Council Ruling. The decision has dismissed any hesitation regarding cash waqf. Cash waqf has been implemented in several states in Malaysia which are Penang, Selangor, Pahang, Melaka, Perak and Terengganu (Mokthar, 2018).

Even though Cash Waqf is still not at the high achievement yet, but it is forecasted that it will has a potential to develop in the future. Based on the research by (Anwar Allah et al., 2014), Cash Waqf has the potential to develop and able to promote the development of Ummah. He estimated that the collection of Cash Waqf in Malaysia could reach RM 4.3 billion a year. He also stated that Penang has a very high potential to develop a Cash Waqf fund based on their planning and marketing strategy. He also estimated that collection of Cash Waqf funds can reach RM 7 million a year.

Nevetheless, Afandi \& Nufus (2010) reported that the collection of cash waqf fund still far from expectation. In Malaysia, the low cash waqf collection level indirectly indicates the awareness about cash waqf is not at a good level. There are also a few factors that might contribute to this situation. This is supported by the research done by Jalil et al., (2017); Allah Pitchay et al., (2018); Ab Fatah et al., (2017); Adeyemi et al., (2016). Hence, there are many studies investigate on the factors that influence the intention for cash waqf contribution.

On the other hand, Fauzi, Yahya, Haron, et al., (2019) demonstrates that online donation shows the tendency of participation by everyone, representing various levels of income. This is because most of people having money and only minimal amount was required for cash waqf participation. People like to help each other, especially in order to get the reward from Allah. In the study reveals that they are increasing number of contributions especially among the IT literate customers. It proves that greater and easy access to online service is a useful mechanism in promoting cash waqf donation. This can be seen in the collection trend of cash waqf fund for three consecutive years. Besides that, the finding also summarize that the online users are influence by trust. It indicates that trust is a determinant factor for internet banking users before consuming their online transaction. In their study shows how online facility affects the donor behaviour in cash waqf contribution.

IT started its era around 1990s, is still rapidly developing today. Malaysia is continuously going through various changes in the agricultural to the industrial aspects to the ICT field. ICT is aided to develop and ensure the growth of national economy especially in 
developing countries (Walsham \& Robey, 2007). Walsham \& Robey, (2007) is surely right about the development of information technology because, as recent studies show digital technology, which is part of ICT, is widely used in Malaysia, beginning in 1874 with the advent of telephone network, followed by the introduction of computer technology in 1966. ICT usage was emphasized in the Eighth Malaysia Plan, where the government started to take the steps to incorporate ICT, followed by the Ninth and Tenth plans where ICT was used as key enabler and one of the components to achieve the major objectives in national development. Hassan et al., (2011) believed that there had been many initiatives taken by the government to achieve the objectives where various programs and projects were carried out such as smart schools, telehealth, research and development clusters, Multimedia Super Corridor, cyber city and many others.

Rapid development of ICT use could be one of the elements that contribute to the economic and social development in Malaysia. It is supported by Kriz \& Qureshi (2009) and Dinc (2016) that ICT is a tool to economic development. In fact, most countries around the world have used various approaches to implement ICT usage in society through community development projects. Therefore, impelmentation of technology usage in cash waqf should be a steppingstone to improve the awareness, provide greater convenience and facilities as well as the increase the collection of cash waqf.

In this reserach, technology usage (TU) is used to identify it's relationship to the intention of cash waqf contribution. The influence of technology acceptance on giving is shown by in the research done by Fauzi, Yahya, Haron, et al. (2019) that the greater the easy access of waqf contribution through technology usage will increase the contribution of cash waqf. It was supported by Tri Kurniawati et al., (2021); Kasri \& Yuniar, (2021); Zheng, (2020); Li et al., (2018) who have positively related between technology usage and intention to donate, and they conclude that intention to make donation influence by technology usage. The satisfaction from donating using the technology increases the intention to donate. Furthermore, they can feel satisfaction from making such donation without being worried having to spend a high amount of money (Tri Kurniawati et al., 2021). Kasri \& Yuniar, (2021) highlighted that facilitating condition has become a factor that significantly influences the intention to use online platforms to pay zakat.

Thus, the effect of technology usage could influence the intention of cash waqf contribution. The effect of technology usage is as follows: waqf $(\mathrm{BI})$.

H1: Technology Usage (TU) has a positive relationship on intention to contribute cash

\section{Methodology}

This study employs quantitative research methodology. Since the objective of this study is to determine the effect of technology usage (TU) to the individual's intention of cash waqf contribution, therefore the best method to employ is a quantitative method. It involves investigation into social or human problems and based on theoretical model tests.

Besides, this study is using descriptive method because it would be able to illustrate the factors that motivate individual contributors to contribute cash waqf based on the data collected using questionnaires. 
This study intends to investigate factors of Muslims to contribute to cash waqf based on technology aspects. Thus, in order to fulfil all the criteria mentioned, the targeted respondents would be working Muslims in public or private sector or self-employed. The respondents must be Muslim and employed person similar to the research of Pitchay et al. (2015) that investigated factors that influence the behavioral intentions of Muslim employees to contribute to cash waqf through employed Muslims.

In this study, 284 questionnaires was distributed. The answer from the respondents would be the findings of this study.

\section{Findings}

Data was analysed through PLS-SEM. All the 284 data were used to get the findings. In PLS-SEM, the data go through two asssessment model which are first, measurement model and structural model.

\section{Assessment of Measurement Model}

In evaluating the measurement model, there are several measures that need to be evaluated such like indicator reliability, internal consistency reliability, convergent validity and discriminant validity. The researcher may proceed to structural model after achieved all the benchmark of the requirement in the first measurement model. The evaluation of measurement model used to assess the value of the outer loadings, Composite Reliability (CR), Average Variance Extracted (AVE), and convergent validity (HTMT). While the evaluation of structural model used to assess R square, path coefficient, Variance Inflation Factor (VIF), confidence interval bias correlated and $Q$ square value.

All indicators have outer loadings of more than 0.708 except for eight indicators, however, only seven indicators namely B6, C2, C3, D4, E5, F1, G4 were removed while the other indicators were retained because it is allowed to remove only $20 \%$ from the total indicators. Thus, indicators with outer loading below than 0.5 were deleted (Hair et al., 2014)

The indicator of the reliability of the item needs the loading to be at least 0.70 for each item in the construct to indicate adequate convergence or internal consistency between the items (Thurasamy et al., 2018). The composite reliability in this study reported in table 1 and the result shows that the construct under this research have $C R$ value more than the threshold value of 0.7 . Hence, the internal consistency reliability is fulfilled.

Table 2: Value of Composite Reliability

\begin{tabular}{|l|l|}
\hline Constructs & Composite reliability \\
\hline Technology Usage-TU & 0.940 \\
\hline
\end{tabular}

AVE with values of more than 0.50 exhibits the ability of the constructs to explain more than half of the variance of its indicators (Hair et al., 2014). The results in this study indicate that the AVE for the construct had achieved a value of more than 0.50 which is 0.797 after deleting seven items as mentioned previously, thus it show that the item fulfil the requirement for achieving the minimum indicator (Fornell \& Larcker, 1981). The result is presented in Table 3 demonstrates the value of AVE and it was achieved minimum of 0.5 . (Hair et. al., 2014). 
Table 3: Value of Average Extract Variance (AVE)

\begin{tabular}{|l|l|}
\hline First Order Constructs & $\begin{array}{l}\text { Average Variance Extract } \\
\text { (AVE) }\end{array}$ \\
\hline Technology Usage-TU & 0.797 \\
\hline
\end{tabular}

In this research, discriminant validity in the measurement model was tested based on the Heterotrait-monotrait ratio (HTMT) criteria (Hair et al., 2014;2019). In order for the construct to achieve discriminant validity based on the HTMT ration, the value of HTMT obtained must not exceed the threshold value of 0.85 . Referring to the threshold value of 0.85 for HTMT.85, the results indicate that the discriminant validity has been established and meets the threshold range of below 0.85 (Hair et al., 2014).

Table 4: Heterotrait- Monotrait (HTMT) in Assessing Discriminant Validity

\begin{tabular}{|c|c|c|c|c|c|c|}
\hline & ATT & BI & PBC & SN & TA & TU \\
\hline TU & 0.536 & 0.496 & 0.615 & 0.527 & 0.823 & \\
\hline
\end{tabular}

Overall, the results obtained in all the tests were satisfactory. Specifically, the indicator loadings for the indicator reliability test and internal consistency had achieved a value of more than 0.708 with AVE for convergent validity tests achieving more than 0.50 . For the discriminant validity test, the values obtained in HTMT ratio are satisfactory (at below 0.85 of HTMT.85) to establish the discriminant validity in the measurement model. Thus, the researcher could proceed to the next step; structural model.

\section{Assessment of Structural Model}

The validity of the structural model is assessed using the coefficient of determination (R2) and path coefficients.

The results in Table 5 indicate the values of VIF (Variance Inflation Factor) for component of technology usage as predictors of behaviour intention which is less than the threshold values of 5 .

Table 5: Result of Collinearity Between Constructs

\begin{tabular}{|l|l|}
\hline & VIF \\
\hline TU & 2.298 \\
\hline
\end{tabular}

The $\mathrm{R} 2$ value indicates the amount of variance in dependent variable that is explained by the independent variable. Thus, a larger R2 value increases the predictive ability of the structural model. It shows in Table 6 below.

Table 6: Assessment of $R^{2}$ value

\begin{tabular}{|c|c|}
\hline Endogenous Constructs & $\mathrm{R}^{2}$ \\
\hline Behavioural Intention & 0.334 \\
\hline
\end{tabular}

According to scholarly research focusing on marketing issues, $R 2$ values of $0.75,0.50$, or 0.25 for endogenous latent variables can be defined as major, moderate, or poor, respectively (Hair et al., 2014). Thus, the R2 values of $33.4 \%$ obtained for firm output as an endogenous construct are moderate. 
Each path connecting two latent variables in the structural model represented a hypothesis. The structural model analysis helps the researcher to confirm or disconfirm each hypothesis as well as determine the strength of the relationship between dependent and independent variables.

The SmartPLS bootstrapping feature is used to produce t-statistics for all directions in order to measure the significant level. The significance level of each relationship is calculated using the t-statistics output. For each hypothesised path, Table 7 lists the path coefficients, observed t-statistics, and significance level. The acceptance or rejection of the suggested hypotheses is decided using the route evaluation findings. The next section goes into how to test the theories that have been formulated.

Table 7: Path Coefficients, Observed T-Statistics, and Significance Level for all Hypothesis Tested

\begin{tabular}{|l|l|l|l|l|l|}
\hline & $\begin{array}{l}\text { Original } \\
\text { Sample (O) } \\
\text { Path } \\
\text { Coefficient/ } \beta\end{array}$ & $\begin{array}{l}\text { Standard } \\
\text { Deviation } \\
\text { (STDEV) }\end{array}$ & $\begin{array}{l}\text { T-Statistics } \\
(\mid \text { O/STDEV|) }\end{array}$ & $\begin{array}{l}\text { Significant } \\
\text { level/ } \\
\text { P Values }\end{array}$ & Result \\
\hline $\begin{array}{l}\text { TU }>> \\
\text { BI }\end{array}$ & 0.144 & 0.069 & 2.1 & 0.036 & Significant \\
\hline
\end{tabular}

In this measurement, if the Q2 is greater than 0 , the structural model is considered to be predictive relevance. Table 8 shows the result of Q2 obtained from the blindfolding procedure as 0.298 .

Table 8: Assessment of Predictive Relevance $Q$

\begin{tabular}{|l|r|r|r|}
\hline & SSO & SSE & $\begin{array}{r}\mathrm{Q}^{2}(=1- \\
\text { SSE } / \text { SSO })\end{array}$ \\
\hline $\mathrm{BI}$ & 1136 & 797.034 & 0.298 \\
\hline
\end{tabular}

\section{Conclusion}

Based on the analysis in this research, technology usage is significant to the research. It can be conclude that technolgy usage created and used for collection cash waqf is important because it will determined the accessibility, convenience and user friendly of the method used by the Muslims. In other words, technology usage would be a vital roles in influencing cash waqf contribution as it would provide convenience facility and easy access for the contributors of cash waqf.

This paper used technology usage in determine factor to enhance cash waqf contribution among Muslims. Hence, this factor could be use a an extended variabe in other theory in order to investigate the factors of contribution of cash waqf. It is according to the originality of this study which use technology usage as extended variable in the Theory of Planned Behaviour, thus it is proposed other study to use this technology usage in their research. Since this study found technology usage is significant to enhance contribution of cash waqf, then this study encourage related waqf institutions to innovate the method of giving awareness and to collect cash waqf with technology advancement implementation. It is relevant in this time since technology is more advance and improve from time to time, and people are more adapt to use technology advancement. Overall, technology usage may provide convenience and flexibility of cash waqf collection, which would attract and encourage more people to 
contribute cash waqf. Cash waqf is one of the way for Muslims to practice philanthropy in their life.

\section{References}

Ab Fatah, N. S., Mansor, N., Ripain, N., \& Endut, W. A. (2017). Waqf Participation and Awareness; An Exploratory Study in the West Coast of Sabah, Malaysia. International Journal of Research Science \& Management, 4(6). https://doi.org/10.18514/MMN.2020.2947

Adeyemi, A. A., Ismail, N. A., \& Hassan, S. S. B. (2016). An empirical investigation of the determinants of cash Waqf awareness in Malaysia. Intellectual Discourse, 24, 501520.

Afandi, A., \& Nufus, D. N. (2010). Analysis on Cash Waqf Return Fund Allocation in Indonesia: A Case Study in Indonesian Waqf Deposit. Tauhid Epistemology In Increasing The Number Of Zakat-Of-Wealth Payers And Its Contribution Toward The Development Of Malaysia Economy, 54-63.

Ahmad, M., Isa, M., Palil, R., \& Dolah, N. H. (2014). Online Waqf Acceptance and Determinant Factors. International Journal of Business, Economics and Law, Vol. 5, Issue 2 (Dec.) ISSN 2289-1552, 5(2), 28-35.

Ahmad, S., \& Muhamed, N. D. (2011). Institusi Wakaf dan Pembangunan Ekonomi Negara : Kes Pembangunan Tanah Wakaf di Malaysia Wakaf Institutions and National Economic Development : A Case on Wakaf Land Development in Malaysia. Prosiding PERKEM VI, 1, 138-147.

Allah Pitchay, A., Mohd Thas Thaker, M. A., Mydin, A. A., Azhar, Z., \& Abdul Latiff, A. R. (2018). Cooperative-waqf model: a proposal to develop idle waqf lands in Malaysia. ISRA International Journal of Islamic Finance, 10(2), 225-236. https://doi.org/10.1108/IJIF07-2017-0012

Amin, H., Abdul-Rahman, A. R., Ramayah, T., Supinah, R., \& Mohd-Aris, M. (2014). Determinants of online waqf acceptance: An empirical investigation. Electronic Journal of Information Systems in Developing Countries, 60(1), 1-18. https://doi.org/10.1002/j.1681-4835.2014.tb00429.x

Ani, N. (2019). BWI : Pertumbuhan Wakaf Masih Lesu. 1-6.

Anwar Allah, P., Ahamed Kameel, M. M., \& Muhammad Yusuf, S. (2014). Priority of Waqf Development among Malaysian Cash Waqf Donors: An AHP Approach. Journal of Islamic Finance, 3(1), 13-22.

https://ikr.inceif.org/bitstream/INCEIF/1374/1/priority_waqf_development_malaysi an_cash_waqf_donors_AHP_approach_yusuf_saleem.pdf

Devadevan, V. (2013). Mobile Banking in India - Issues \& Challenges. International Journal of Emerging Technology and Advanced Engineering, 3(6), 516-520. http://citeseerx.ist.psu.edu/viewdoc/download?doi=10.1.1.413.6951\&rep=rep1\&typ $\mathrm{e}=\mathrm{pdf}$

Dinc, M. (2016). Introduction to Regional Economic Development. In Introduction to Regional Economic Development (Issue December 2015). https://doi.org/10.4337/9781785361357

Fauzi, M. H., Yahya, S., Hanaysha, J. R., Haron, M. S., \& Abu Zahrin, S. N. (2019). The Impact of Trust in Cash Waqf Contribution: A Case Study of Wakaf Selangor Muamalat (WSM) Service Of Bank Muamalat Malaysia Berhad (BMMB). International Journal of Business, Economics and Law, 18(2), 1-10. 
Fornell C \& Larcker F David. (1981). Evaluating Structural Equation Models with unobservale variables and measurement error. Journal of Marketing Research, 18(1), 39-50

Hair, J., Sarstedt, M., Hopkins, L., \& Kuppelwieser, V. G. (2014). Partial least squares structural equation modeling ( PLS-SEM ) An emerging tool in business research. European Business Review, 26(2), 106-121. https://doi.org/10.1108/EBR-10-2013-0128

Hair, Joseph F., Risher, J. J., Sarstedt, M., \& Ringle, C. M. (2019). When to use and how to report the results of PLS-SEM. European Business Review, 31(1), 2-24. https://doi.org/10.1108/EBR-11-2018-0203

Hasanah, U., \& Pranata, D. (2019). Waqf Financial Tecnology in Startup Capital. International Conference on IslamicDevelopment Studies. https://doi.org/10.4108/eai.10-92019.2289331

Hassan, M. A., Samah, B. A., Shaffril, H. M., \& D'Silva, J. L. (2011). Perceived usefulness of ICT usage among JKKK members in Peninsular Malaysia. Asian Social Science, 7(10), 255266. https://doi.org/10.5539/ass.v7n10p255

Jalil, M. I. A., Pitchay, A. A., \& Yahya, S. (2017). Cash Waqf and Preferred Method of Payment: Case of Malaysia Using an AHP Approach. Revitalization of Waqf for Socio-Economic Development, 2(January 2019), 187-206. https://doi.org/10.1007/978-3-030-184490_10

Johari, F. (2020). Personal Communication January 2nd, 2020.

Kasri, R. A., \& Yuniar, A. M. (2021). Determinants of digital zakat payments : lessons from Indonesian experience. https://doi.org/10.1108/JIABR-08-2020-0258

Khademolhoseini, M. (2008). Cash-Waqf a New Financial Instrument for Financing Issues : an Analysis of Structure and Islamic Justification of Its Commercialization. Imam Sadiq University, 1-17.

Kriz, K., \& Qureshi, S. U. E. (2009). The Role of Policy in the Relationship between ICT Adoption and Economic Development: A Comparative Analysis of Singapore and Malaysia. GlobDev 2009, 1-31. http://aisel.aisnet.org/globdev2009/13

Li, Y. Z., He, T. L., Song, Y. R., Yang, Z., \& Zhou, R. T. (2018). Factors impacting donors' intention to donate to charitable crowd-funding projects in China: a UTAUT-based model. Information Communication and Society, 21(3), 404-415. https://doi.org/10.1080/1369118X.2017.1282530

Mahbubi, M. (2017). Unleashing the potential of cash 'waqf. News Straits Times. https://www.nst.com.my/opinion/columnists/2017/06/247185/unleashingpotential-cash-waqf

Mat Doa, M. B. (2020). Yayasan Wakaf Malaysia.

Mohd Isa, M. (2014). The Acceptance of Online Waqf in Islamic Banking Institutions Master in Islamic Finance and Banking [Universiti Utara Malaysia]. http://etd.uum.edu.my/4685/2/s812880_abstract.pdf

Mokthar, M. Z. (2018). Penang Muslims' Perception on Factors Influencing Intention to Give Cash Waqf. International Journal of Academic Research in Business and Social Sciences, 8(5), 864-874. https://doi.org/10.6007/ijarbss/v8-i5/4225

Nasiri, A., Noori, A., \& Salleh, M. C. M. (2019). Acceptance and Practices of Cash WAQF among University's Students. International Journal of Academic Research in Accounting, Finance and Management Sciences, 9(3), 38-48. https://doi.org/10.6007/ijarafms/v9i3/6325

Osman, A. F., Mohammed, M. O., \& Amin, H. (2014). An Analysis of Cash Waqf Participation Among Young Intellectuals. Proceedings of Seminar Waqf Iqlami 2014, 7-20. 
Peek, S. T. M., Wouters, E. J. M., van Hoof, J., Luijkx, K. G., Boeije, H. R., \& Vrijhoef, H. J. M. (2014). Factors influencing acceptance of technology for aging in place: A systematic review. International Journal of Medical Informatics, 83(4), 235-248. https://doi.org/10.1016/j.ijmedinf.2014.01.004

Pitchay, A. A., Meera, A. K. M., \& Saleem, M. Y. (2015). Factors influencing the behavioral intentions of muslim employees to contribute to cash-waqf through salary deductions. Journal of King Abdulaziz University, Islamic Economics, 28(1), 63-100. https://doi.org/10.4197/Islec.28-1.3

Shukor, S. A., Anwar, I. F., Aziz, S. A., \& Sabri, H. (2017). Muslim attitude towards participation in cash WAQF: Antecedents and consequences. International Journal of Business and Society, 18(S1), 193-204.

Thurasamy, R., Mohamad, O., Omar, A., \& Marimuthu, M. (2009). Technology Adoption among Small and Medium Enterprises (SME's): A Research Agenda. International Journal of Social, Behavioral, Educational, Economic, Business and Industrial Engineering, 3(May), 512-515.

Tri Kurniawati, D., Rosita, N. H., \& Anggraeni, R. (2021). The role of emotional marketing and UTAUT on donation intention through social media. International Journal of Research in Business and Social Science (2147-4478), 10(1), 38-46. https://doi.org/10.20525/ijrbs.v10i1.1026

Wadi, D. A., \& Nurzaman, M. S. (2020). Millennials Behaviour towards Digital Waqf Innovation. International Journal of Islamic Economics and Finance (IJIEF), 3(3), 1-30. https://doi.org/10.18196/ijief.3232

Walsham, G., \& Robey, D. (2007). Special Issue on Information Systems in Developing Countries. Special Issue on IS in Developing Countries, 31(2), 317-326.

Zheng, Y. (2020). Using Mobile Donation to Promote International Fundraising: A Situational Technology Acceptance Model. International Journal of Strategic Communication, 14(2), 73-88. https://doi.org/10.1080/1553118X.2020.1720026 